\title{
Role of Thrombin in Tumor Angiogenesis, Implantation, and Metastasis
}

\author{
Simon Karpatkin \\ Department of Medicine, New York University Medical Center, New York, N.Y., USA
}

Most tumors have constitutively active tissue factor on their surface, capable of generating thrombin into the surrounding environment. The role of thrombin in tumor growth and metastasis is well documented. Thrombin induces a malignant phenotype by enhancing tissue adhesion and cell growth in vitro and in vivo in mice. Thrombin binds to tumor cells making them 2-3 fold more adhesive to platelets, fibronectin, von Willebrand factor and microvascular endothelium. Thrombin-treated tumor cells have $\sim 2$ fold increased growth in vitro. In vivo, thrombintreated tumor cells enhance subcutaneous tumor cell growth 18 fold and experimental pulmonary metastasis (tumor volume) 10-156 fold following ligation of their PAR-1 receptor (after 17-21 days of implantation), respectively.

This review focuses on two areas of the thrombininduced malignant phenotype. (1) The role of thrombin in tumor-associated angiogenesis; (2) The role of thrombin in tumor implantation and seeding.

\section{Thrombin Induces Neoangiogenesis in a Physiologically Intact in vivo Membrane}

Thrombin $(0.1 \mathrm{u} / \mathrm{ml})$ induced neoangiogenesis in the chick chorioallantoic membrane over a $24-72 \mathrm{~h}$ period by $\sim 2-3$ fold. This was inhibited by the potent thrombin inhibitor, hirudin and shown to have its mode of action by ligation of the thrombin protease-activated receptor, PAR-1. The thrombin activation peptide, SFLLRNPNDKYEPF $(200 \mu \mathrm{M})$ also enhanced neoangiogenesis $\sim 2-3$ fold. Thrombin-induced neoangiogenesis was accompanied by the induction of vascular endothelial growth factor (VEGF) and angiopoietin-2 (Ang-2) mRNA at $24-48 \mathrm{~h}$ ( $\sim 2$ fold) as determined by semi-quantitative RT-PCR. Thrombin induced neoangiogenesis was inhibited to baseline level by the specific angiogenesis receptor inhibitors KDR-Fc (vs. VEGF) and Tie-2-Fc (vs. Ang-2), as well as the non-specific angiogenesis inhibitor thrombospondin-1. Thrombininduced neoangiogenesis was also inhibited to baseline level by agents known to inhibit thrombin receptor signaling in other cells: G-coupled protein receptor inhibitor, pertussis toxin $(40 \mathrm{pg} / \mathrm{egg})$, protein kinase $\mathrm{C}$ inhibitor, bisindolylmaleimide (1 um/egg), MAP kinase inhibitor, PD980598 (10 um/egg) and PI3 kinase inhibitor, LY294002 (0.25 um/egg).

\section{Tumor Implantation and Seeding are Induced by Endogenous Thrombin}

Hirudin is a potent thrombin inhibitor capable of inactivating adherent thrombin within the tumor thrombus. Nude mice (5 in each group) were injected both subcutaneously

\begin{tabular}{ll}
\hline KARGER & (c) 2003 S. Karger AG, Basel \\
Fax +4161306 1234 $34832 / 03 / 0337-0054 \$ 19.50 / 0$ \\
$\begin{array}{l}\text { E-Mail karger@karger.ch } \\
\text { www.karger.com }\end{array}$ & $\begin{array}{l}\text { Accessible online at: } \\
\text { www.karger.com/journals/pht }\end{array}$
\end{tabular}

\footnotetext{
Simon Karpatkin, MD

Department of Medicine, New York University Medical Center

550 First Ave; Room 439, New York, NY 10016-6481 (USA)

Tel. + 1212263 5609, Fax +1 2122638444
}

E-Mail simon.karpatkin@med.nyu.edu 
and intravenously with $1 \times 10^{6}$ human A549 lung cancer cells (non-small cell) as well as breast cancer MDA.MB. 231 cells. Hirudin, $10 \mathrm{mg} / \mathrm{kg}$ was given i.p. $5 \mathrm{~min}$ before and $4 \mathrm{~h}$ after tumor inoculation and mice followed for various time intervals (16-77 days). Impaired subcutaneous tumor growth was particularly marked with hirudin treatment at early time points following tumor nodule recognition: 3-4 fold less with A549 cells at 12-15 days and 2-3 fold less at 41 days. Similar results were obtained with MDA.MB.231 cells: 10-11 fold less at 7-9 days and 1.5-3 fold less at $12-16$ days. A lag period of 2-5 days was noted before appearance of tumor nodules in animals treated with hirudin compared to controls. Additional hirudin given everyday for 5 days or every other day for 10 days showed no enhancement over the initial 2 injections. When mice injected with MDA.MB.231 cells were treated with hirudin after the appearance of $0.4 \mathrm{~cm}^{2}$ nodules at 8 days, no difference in tumor growth was noted between treated and control mice at 0 and 14 days. Animal survival was followed after intravenous injection of A549 cells with and without hirudin, as above. In 4 different experiments all hirudin-treated animals were alive at 38-77 days whereas $60 \%$ of control animals were dead in 2 experiments and $100 \%$ dead in 2 other experiments. Autopsied lungs of dead animals were loaded with tumor metastasis. In culture, hirudin $\times 3$ days had no effect on growth of MDA.MB.231 cells $\times 7$ days.

B16F10 cells were transfected with GFP (fluorescent cells) and implanted subcutaneously into syngeneic mice. Blood samples were removed at 0, 10, 15 and 21 days and enumerated by fluorescence flow cytometry. Hirudin treatment $(5 \mathrm{mg} / \mathrm{kg}$ day $\times 21$ days), resulted in marked impairment of arterial-seeded cells, compared to PBS-treated animals, 100 and 700 fold at 15 and 21 days, respectively. The same applied for tumor cells within the lung, utilizing 1 week cultures of minced-lung tissue for analysis of the data. Hirudin treatment inhibited metastasis 20 and 400 fold at 5 and 10 days respectively. Thus angiogenesis, tumor implantation and pathophysiologic metastasis is stimulated by thrombin/thrombosis.

\footnotetext{
References

Caunt, et al: Thrombin induces neoangiogenesis in the chick chorioallantoic membrane (submitted). Huang, et al: Thrombin induces increased expression and secretion of VEGF from human FS4 fibroblasts, DU145 prostate cells and CHRF megakaryocytes. Thromb Haemostas 2001;86: 1094.

Huang, et al: Thrombin induces increased expression and secretion of angiopoietin-2 from human umbilical vein endothelial (HUVE) cells. Blood 2002;99:1646.
}

Role of Thrombin in Tumor Angiogenesis, Implantation, and Metastasis
Pathophysiol Haemost Thromb 2003;33(suppl 1):54-55 